\title{
Concept and Implementation of Online Game-Based Learning Approach in Distance Learning
}

\author{
Esti Jayanti \\ SD Negeri Pasucen 01 \\ esti.jyuubi@gmail.com
}

\section{Article History}

received 3/12/2020

revised $17 / 12 / 2020$

accepted 31/12/2020

\begin{abstract}
Education is an endeless learning process either formally or nonformally. To achieve student's goal, they must develop their potential. This potential can be achieve through learning that is education. In this pandemic situation, student's doing online learning. But students don't have any meaningfull learning in this activities. Students have been enamored in online games. The purpose of this study is to describe 1. Online game-based learning approach, 2. Implementation of a online game-based learning in distance learning. The result of this study are: (1) Online game-based learning is a learning approach based on software.; (2) the implementation of the online game-based learning approach in distance learning is combining data collection, system analysis, coding, implementation, and maintenance. The conclusion of this study are online game-based learning is an educational system where teacher can apply an online game for cognitive interest and learning motivation that students need.
\end{abstract}

Keywords: game-based learning, distance learning, online game

\begin{abstract}
Abstrak
Pendidikan adalah sebuah proses belajar tanpa akhir baik secara formal maupun nonformal. Untuk mencapai tujuan peserta didik, mereka harus mengembangkan kemampuan mereka. Kemampuan ini dapat dicapai melalui pembelajaran yaitu pendidikan. Di situasi pandemi saat ini, peserta didik melakukan kegiatan pembelajaran secara daring. Tetapi dalam kegiatan tersebut peserta didik tidak mendapatkan pembelajaran yang berkesan. Peserta didik lebih tertarik pada game daring. Tujuan dari kajian ini untuk mendeskripsikan 1. Pendekatan online game-based learning, 2. Implementasi pendekatan online game-based learning dalam pembelajaran jarak jauh. Hasil dari kajian ini yaitu online game-based learning menggabungkan perolehan data, analisi sistem, pengkodean, implementasi, dan pemeliharaan. Simpulan dar kajian literatur ini yaitu pendekatan online game-based learning adalah sebuah sistem yang diterapkan dalam proses pendidikan, dimana guru dapat mengaplikasikan sebuah permainan daring untuk kebutuhan minat kognitif dan motivasi belajar
\end{abstract}

Kata kunci: pembelajaran berbasis permainan, pembelajaran jarak jauh, permainan daring

Social, Humanities, and Education Studies (SHEs): Conference Series https://jurnal.uns.ac.id/shes

p-ISSN 2620-9284

e-ISSN 2620-9292

This work is licensed under a Creative Commons Attribution-ShareAlike 4.0 International License. 


\section{PENDAHULUAN}

Di Indonesia bahkan dunia saat ini mengalami sebuah goncangan karena adanya pandemi Covid-19 yang merebak di seluruh bagian bumi. Interaksi dan mobilitas yang dulu bebas tanpa hambatan sekarang sangat terbatasi sebagai bentuk penvegahan penyebaran virus tersebut. Hal ini memaksa untuk terjadinya perubahan sistem pada hampir seluruh bidang kehidupan, salah satunya adalah di bidang pendidikan. Pendidikan merupakan sebuah proses belajar tanpa henti untuk mendapatkan informasi pengetahuan untuk mengembangkan potensi seseorang yang dapat ditempuh baik secara formal maupun nonformal. Artinya pendidikan seseorang sangat penting untuk kemajuan dan perkembangan seseorang. Pendidikan formal sebelum masa pandemi Covid-19 dilaksanakan secara tatap muka dimana pendidik bertemu dan berinteraksi langsung dengan peserta didik. Sedangkan pendidikan formal pada masa pandemi ini menerapkan pembelajaran jarak jauh atau Distance Learning.

Hal ini dikemukakan oleh Hanelahi,D \& Atmaja, K (2020) yang berpendapat bahwa pembelajaran jarak jauh merupakan sistem pembelajaran yang lokasi peserta didik dengan tutur berjauhan tetapi pembelajaran tetap dapat berlangsung yang sangat bergantung pada dukungan media digital.

Dewasa ini, hampir semua anak yang suka bermain game online. Pada dasarnya setiap manusia memiliki ketertarikan pada game. Bahkan banyak anak yang tidak mengerjakan kewajibannya sebagai peserta didik demi bermain game online. Salah satu penyebab peserta didik lebih tertarik pada game daripada pembelajaran adalah karena pada saat kegiatan pembelajaran masih menggunakan metode yang monoton. Sehingga anak kurang merasa tertantang dan rendah partisipasinya dalam pembelajaran. Sedangkan pada game, anak dapat berpartisipasi aktif pada permainan, selain itu adanya gambar visual dan warna-warna yang menarik juga menjadi salah satu alasan anak sangat tertarik pada game.

Hal ini menunjukkan bahwa proses pembelajaran jarak jauh di sekolah belum optimal. Pembelajaran jarak jauh seharusnya menjadi salah satu solusi pada bidang pendidikan pada masa pandemi saat ini. Akan tetapi, kegiatan pembelajaran jarak jauh yang monoton masih kurang mampu menarik perhatian peserta didik. Apalagi di era digital saat ini kemajuan game online yang sangat maju dan canggih juga ikut berpengaruh mengalihkan perhatian peserta didik. Jika hal ini terus terjadi tanpa adanya tindakan untuk memperbaiki metode pendidikan maka lama kelamaan peserta didik akan semakin kurang tertarik pada pendidikan dan pengembangan dirinya. Fenomena tersebut di bidang pendidikan merupakan PR bagi semua pendidik.

Berdasarkan masalah di atas, diperlukan pembelajaran yang dapat menggabungkan kegiatan pembelajaran jarak jauh dengan game online yang meluas di kalangan peserta didik. Sehinggan memunculkan metode online game-based learning bagi peserta didik.

Menurut Ferdian, E.Y \& Wulandari, F.D (2021:8) "fitur game online bersifat menghibur dan mengurangi tekanan, kebosanan serta mengurangi tuntutan pembelajaran atau tugas sekolah".

Menurut Prasetya, dkk dalam Mulidina, M.A., dkk. (2018: 114) "game based learning merupakan bentuk pembelajaran berpusat pada pebelajar yang menggunakan game elektronik atau digital untuk tujuan pembelajaran".

Berdasarkan pendapat diatas, fitur game online yang bersifat menghibur dan mengurangi tekanan. Sehingga dalam pengimplementasian game online pada proses pembelajaran jarak jauh dapat meningkatkan ketertarikan dan pengetahuan peserta didik dengan cara yang menyenangkan dan tidak membosankan. Serta sangat sesuai dengan era digital dan pada masa pandemi saat ini. Selain itu, pembelajaran dengan online game-based learning ini membuat peserta didik belajar dengan cara yang 
menyenangkan dan membebaskan peserta didik dari tuntutan tugas sekolah yang dianggap memberatkan.

\section{HASIL DAN PEMBAHASAN}

Game based learning merupakan sebuah sistem yang diterapkan dalam proses pendidikan, dimana pengguna (dosen) dapat mengadopsi sebuah permainan untuk kebutuhan minat kognitif dan motivasi belajar (Vusić, Bernik, \& Geček dalam Winata, K.R. \& Setiawan I.M.D (2020:199)). Menurut Adams dalam Novrialdy, E. (2019: 149) "Game online adalah permainan yang dapat dimainkan oleh banyak orang pada waktu bersamaan melalui jaringan internet". Hanelahi,D \& Atmaja, K (2020) berpendapat bahwa pembelajaran jarak jauh merupakan sistem pembelajaran yang lokasi peserta didik dengan tutur berjauhan tetapi pembelajaran tetap dapat berlangsung yang sangat bergantung pada dukungan media digital. I

\section{Karakter Pendekatan Game-Based Learning}

Karakter-karakter pendekatan game-based learning adalah sebagai berikut:

1. Menarik dan mengasyikan

Pendekatan game-based learning mampu membuat peserta didik memahami materi pelajaran dengan mudah dengan cara yang menarik dan menyenangkan.

2. Berdasarkan pada pengalaman

Dengan menggunakan game, peserta didik mampu memahami dengan sendirinya melalui proses trial and error dimana peerta didik dapat mencoba lagi dengan Menyusun rencana dan strateginya sendiri agar dapat mencapai tujuan/ misi dalam game.

3. Ada tantangan yang bisa diseseuaikan

Pada game terdapat tingkat kesulitan mulai dari yang mudah, normal, dan sulit. Pada game edukasi yang digunakan dalam pembelajaran, peserta didik dapat memilih tingkat kesulitan sesuai dengan kemampuannya. Kemudian jika berhasil melewati tingkat awal peserta didik dapat melanjutkan ke tingkat berikutnya.

4. Interaktif dan umpan balik

Pada game-based learning ini peserta didik dapat dilakukan secara interaktif. Dari game yang telah dimainkan tersebut peserta didik juga mampu merefleksikan dan menarik kedimpulan dari hasil tindakan yang dibuat dalam game.

5. Sosial dan Kerjasama

Game-based learning ini juga diharapkan dapat melatih kemampuan sosial peserta didik.

\section{Komponen utama Game-Based Learning}

Menurut McGonigal dalam Putri, V.V.E., \& Asrori, M.A.R (2019: 142) fitur-fitur utama dari pendekatan pembelajaran berbasis game daring adalah sebagai berikut :

a. Tujuan merupakan hasil yang akan diperoleh oleh peserta dari aktivitasnya di dalam game. Sebuah tujuan akan menjadi bagian dari rancangan dari game akan membuat peserta memilioki sebuah sense of purpose.

b. Aturan merupakan Batasan-batasan mengenai bagaimana caranya pemain dapat mencapai tujuannya di dalam game.

c. Feedback system menunjukkan kepada peserta seberapa dekat mereka dengan tujuan yang ingin diraih di dalam permainan.

d. Voluntary participation merupakan landasan dasar dari kesediaan jumlah orang untuk bermain bersama.

\section{Implemantasi Pendekatan Online Game-Based Learning}

Seperti telah dipaparkan sebelumnya bahwa pembelaran jarak jauh masih memiliki kekurangan yang dalam menarik peserta didik untuk berpartisipasi dalam 
pembelajaran. Serta munculnya fenomena game online yang sangat meluas membuat anak lebih tertarik bermain game online daripada belajar. Oleh karenanya diperlukan pendekatan yang tepat, salah satunya adalah online game-based learning. Pada penerapan atau implementasi online game-based learning guru harus bisa menerapkan dan mengakses teknologi digital online. Menurut Dewi, N.P. \& Listiowarni, I. (2019) bahwa implementasi dari pendekatan game-based learning dapat dilihat dari bagan berikut ini:

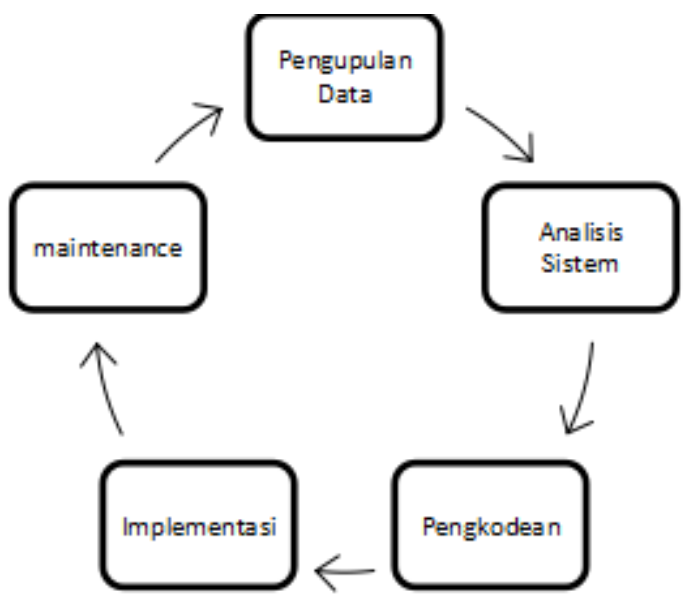

Gambar 1. Pendekatan game-based learning

Pada bagan tersebut dapat terlihat bahwa pendekatan game-based learning terlaksana saling berkaitan dan terjadi memiliki siklus berputar. Jika dicermati lebih rinci untuk masing-masing kegiatan tidak hanya berlangsung sekali tetapi terus berkaitan berulangkali. Tahapan maintenance bukanlah tahapan akhir dari pendekatan game-based learning. Tetapi akan terjadi perputaran kembali ke tahapan awal yaitu pengumpulan data untuk pengembangan versi atau terjadinya erroe pada perangkat lunak yang dikembangkan.

\section{Penjelasan bagan}

Pada setiap kegiatan tersebut dilakukan oleh guru sebelum guru memulai kegiatan pembelajaran. Implementasi dari pembelajaran tersebut dapat dijabarkan berdasarkan penjelasan di bawah ini.

a) Pengumpulan Data

Pada tahap pengumpulan data dilakukan dengan tujuan untuk memperoleh data yang sesuai dengan keperluan, kemampuan, dan gaya belajar peserta didik. Tapap pengumpulan data dapat dilakukan dengan cara pengamatan secara langsung maupun wawancara sederhana dengan peserta didik.

b) Analisis sistem

Tahap analisi sistem ini dilaksanakan setelah penumpulan data selesai dilaksanakan. Pada analisis sistem ini mulai kegiatan perancangan sebuah perangkat lunak, mulai dari sketsa, grafis, penggambaran, muatan pelajaran yang akan dimasukkan dalam perangkat lunak.

c) Pengkodean

Tahap selanjutnya adalah tahap pengkodean (coding). Tahap ini juga tidak kalah penting dari tahap analisis sistem. Berdasarkan tahap analisis sistem yang telah dilakukan pada tahap pengkodean dilakukan perakitan setiap komponen game menjadi suatu kesatuan game yang utuh.

d) Implementasi 
Tahap implementasi merupakan tahap peluncuran perangkat lunak yang dirancang dan dibangun. Uji coba game edukasi yang dibuat juga masuk dalam tahapan ini. Setelah selesai diuji coba, maka peserta didik dapat menggunakan game edukasi yang dibuat tersebut.

e) Maintenance

Tahap maintenance (pemeliharaan) ini dilaksanakan setelah tahap implementasi. Pada tahap ini, setelah game digunakan maka perlu adanya pemeliharaan misalnya memperbaiki kerusakan atau pembaruan versi game edukasi tersebut.

Pendekatan online game-based learning ini memiliki kelebihan dan kelemahan tersendiri. Kelebihan pendekatan ini yaitu; 1) peserta didik merasa nyaman, menyenangkan, dan menumbuhkan semangat untuk belajar; 2) pemahaman peserta didik lebih baik karena lebih berkesan dan bertahan lama di ingatan peserta didik; 3) membuat peserta didik menjadi lebih aktif dan secara tak langsung membiasakan peserta didik untuk berpikir kritis; 4) guru dan peserta didik dapa mengevaluasi secara langsung kemampuan pemahaman peserta didik pada saat permainan.

Sementara itu, kelemahan dari online game-based learning ini yaitu; 1) membutuhkan alat dan media yang memadai, misalnya hp android dan internet; 2) permainan bersifat daring jadi sangat bergantung pada kekuatan jaringan di rumah peserta didik; 3) jika alat atau media mendadak bermasalah maka peserta didik harus mencari solusi alternatif untuk dapat mengikuti game edukasi.

Saat ini sudah cukup banyak aplikasi maupun website game online yang dapat digunakan guru dalam proses pembelajaran. Tentu saja pengembangkan dan Langkah online game-based learning ini sangat dipengaruhi oleh kemauan belajar serta kemampuan guru untuk menerapkan pendekatan ini agar dapat berjalan dengan baik dan lancar.

\section{SIMPULAN}

Pendekatan online game-based learning adalah sebuah sistem yang diterapkan dalam proses pendidikan, dimana guru dapat mengaplikasikan sebuah permainan daring untuk kebutuhan minat kognitif dan motivasi belajar. Implementasi online gamebased learning dalam pembelajaran adalah menerapkan suatu pembelajaran yang mencakup seluruh komponen-komponen menggunakan perangkat lunak yang telah dibuat. Melalui pembelajaran dengan menggunakan pendekatan online game-based learning diharapkan peserta didik dapat memiliki pemahaman dan berkesan pada kegiatan belajar peserta didik.

\section{DAFTAR PUSTAKA}

Dewi, N.P. \& Listiowani, I. (2019). Implementasi Game Based Learning pada Pembelajaran Bahasa Inggris. Jurnal Resti (Rekayasa Sistem dan Teknologi Informasi. 3 (2), 124-130.

Ferdian, E.Y. \& Wulandari, F. D (2021). Implementasi Self Control untuk Mengurangi Kecanduan Game Online pada Peserta Didik di Masa Pandemi Covid-19. Jurnal Bikotetik (Bimbingan Konseling : Teori dan Praktik, 05 (01), 1-48.

Hanelahi, D. \& Atmaja, K. (2020). Literasi Digital dalam Peningkatan Kompetensi Peserta Didik Distance Learning di Homeschooling. Jurnal Pendidikan Untuk Semua, 4 (4), 112-129.

Kejarcita. (2020). 5contoh Game Based Learning yang Bisa Dicoba oleh Guru. Diakses pada 6 Juli 2020, dari https://www.gramedia.com/best-seller/cara-menulis-daftarpustaka/

Mahardini, T., dkk. (2018). Research Based Learning (RBL) to Improve Critical Thingking Skills. Social, Humanities, and Education Studies (SHEs): Coference Series. 1 (2), 466-473. 
Mulidina, M.A., Susilaningsih, \& Abidin, Z. (2018). Pengembangan Game Based Learning Berbasis Pendekatan Saintifik pada Siswa Kelas IV Sekolah Dasar. Jinotep, 4 (2), 113-118.

Novrialdy, E. (2019). Kecanduan Game Online pada Remaja: Dampak dan Pencegahannya. Buletin Psikologi. 27 (2), 148-158.

Putri, V.V.E. \& Asrori, M.A.R. (2019). Pemanfaatan Digital Game Base Learning dengan Media Aplikasi kahoot.It untuk Meningkatkan Interaksi Pembelajaran. Inspirasi; Jurnal IImu-IImu Sosial. 16 (2). 141-150.

Winatha, K.R. \& Setiawan, I.M.D (2020). Pengaruh Game-Based Learning terhadap Motivasi dan Prestasi Belajar. Scholaria: Jurnal Pendidikan dan Kebudayaan, 10 (3), 198-206.

Zamzami, N.D., Nurhayati, N., \& Salimi, M. (2018). Concept and Implementation of The Whole Language Approach in Indonesia Language Learning. Social, Humanities, and Education Studies (SHEs): Coference Series. 1 (2), 314-319. 